\title{
PENGARUH BUDAYA DIGITAL TERHADAP KINERJA KARYAWAN DI YAYASAN PENDIDIKAN TELKOM (STUDI KASUS KANTOR BADAN PELAKSANA KEGIATAN YPT)
}

\author{
Ary Ferdian \\ Prodi S1 Manajemen Bisnis Telekomunikasi dan Informatika, Fakultas Ekonomi dan Bisnis, \\ Universitas Telkom \\ ary.ferdian@gmail.com \\ Annisaa Rahmawati \\ Prodi S1 Manajemen Bisnis Telekomunikasi dan Informatika, Fakultas Ekonomi dan Bisnis, \\ Universitas Telkom \\ anisarahma147@gmail.com
}

\begin{abstract}
ABSTRAK
Yayasan Pendidikan Telkom (YPT) merupakan lembaga yang bergerak di bidang pendidikan dengan kantor pusat pengelolaanya dikenal dengan sebutan Lakhar (Pelaksana Harian). Data Nilai Kinerja Individu (NKI) karyawan masih fluktuatif dan bahkan terjadi penurunan pada tahun 2017 untuk kategori P1 (Istimewa) dan P2 (Baik Sekali). Sementara preliminary study budaya digitalnya sudah terimplementasi cukup baik, namun jika ditelaah lebih mendalam ada beberapa dimensi yang masih rendah. Tujuan dari penelitian ini adalah untuk mengetahui budaya digital yang diterapkan, kinerja karyawan yang ada, dan seberapa besar pengaruh budaya digital terhadap kinerja karyawan YPT. Penelitian ini menggunakan metode kuantitatif dengan teknik pengumpulan data kuesioner yang disebarkan kepada 74 karyawan YPT dan data dianalisis menggunakan metode regresi linier sederhana dengan bantuan program SPSS versi 25. Pengolahan data menunjukkan hasil bahwa budaya digital yang diterapkan dan kinerja karyawan di YPT tergolong sangat tinggi. Budaya digital juga memiliki pengaruh positif sebesar 39,5\% terhadap kinerja karyawan di YPT. Perusahaan sebaiknya mempertahankan dan meningkatkan penerapan budaya digital melalui beberapa metode seperti kegiatan brainstorming atau focus group discussion yang dapat mengembangkan potensi karyawan untuk meningkatkan kinerjanya.
\end{abstract}

Kata Kunci:

Budaya Digital, Kinerja Karyawan, Regresi Linier Sederhana, Kuantitatif, SPSS versi 25

\begin{abstract}
Yayasan Pendidikan Telkom (YPT) is an institution engaged in education with its management head office known as Lakhar (Daily Executor). Employee Individual Performance Values (NKI) data are still volatile and even decreased in 2017 for the P1 (Special) and P2 (Very Good) categories. While the digital culture preliminary study has been implemented quite well, but if examined in more depth there are several dimensions that are still low. The purpose of this study was to determine the digital culture that was applied, the performance of existing employees, and how much influence digital culture had on YPT employee performance. This study uses a quantitative method with questionnaire data collection techniques distributed to 74 YPT employees and the data are analyzed using a simple linear regression method with the help of SPSS version 25. Data processing shows the results that the digital culture is applied and the performance of employees at YPT is very high. Digital culture also has a positive influence of $39.5 \%$ on employee performance at YPT. Companies should maintain and improve the application of digital culture through several methods such as brainstorming or focus group discussions that can develop the potential of employees to improve their performance.
\end{abstract}

Keywords:

Digital Culture, Employee Performance, Simple Linear Regression, Quantitative, SPSS version 25 


\section{PENDAHULUAN}

Teknologi digital bertanggung jawab untuk laju perubahan eksponensial dalam industri dan masyarakat saat ini. Kekuatan komputasi yang luar biasa selalu aktif dalam bentuk high bandwidth internet access, mobile devices, wearables, bio-tech, artificial intelligence, dan virtual reality ada di mana-mana. Hal tersebut hanyalah beberapa teknologi kunci yang mampu mengubah dunia tempat di mana kita tinggal dan bekerja. Digital mirip dengan gangguan (disruption). Pemimpin yang memimpin dunia adalah mereka yang memimpin dunia digital. Gangguan, inovasi, turbulensi, perubahan, dan persaingan merupakan kata-kata yang mendefinisikan dunia kita saat ini. Jika kita tidak menyadari hal tersebut, maka kita sudah masuk dalam kesulitan. Artinya bahwa gelombang perubahan ke ranah digital teknologi sudah berlangsung, sehingga kita harus siap dan mampu untuk menghadapinya agar mampu untuk tetap bertahan (Brett, 2019).

Perubahan ke ranah teknologi digital ini selaras dengan adanya penerapan konsep revolusi Industri 4.0. Industri 4.0 adalah industri yang menggabungkan teknologi otomatisasi dengan teknologi cyber dan merupakan tren otomatisasi serta pertukaran data dalam teknologi manufaktur. Di dalam Industri 4.0 terdapat sistem cyber-fisik, Internet of Things (IoT), komputasi awan dan komputasi kognitif (Igen, 2018). Beberapa negara yang sudah memiliki programprogram untuk mendukung industrinya menuju Industri 4.0 yaitu Jerman, Inggris, Amerika Serikat, China, India, Jepang, Korea, dan Vietnam (Endarwati, 2017). Di Indonesia sendiri, untuk menghadapi revolusi Industri 4.0 pemerintah meluncurkan Roadmap Implementasi Industri 4.0 yang telah dibuat oleh Kementerian Perindustrian dengan nama Making Indonesia 4.0. Program ini sebagai antisipasi kecepatan perubahan industri sekarang ini (Novalius, 2018). Guna mencapai sasaran Industri 4.0 melalui Making Indonesia 4.0 tersebut, lima sektor manufaktur yang akan menjadi percontohan untuk memperkuat fundamental struktur industri Tanah Air yaitu Industri Makanan dan Minuman, Industri Otomotif, Industri Elektronik, Industri Kimia, dan Industri Tekstil (Kementrian Perindustrian Republik Indonesia, 2018). Revolusi Industri 4.0 membuat adanya transformasi organisasi 
pemerintah yang tidak hanya sekedar downsizing dan prosedural semata, namun lebih kepada fundamental seperti pola kerja, budaya organisasi, dan nilai-nilai strategis yang dikembangkan. Transformasi organisasi pemerintah ini sangat dipengaruhi oleh gaya kepemimpinan, budaya kerja, proses kerja, kekuatan kerja, dan struktur organisasi yang dikembangkan (Cahyono, 2018). Oleh sebab itu, budaya digital juga termasuk kedalam salah satu faktor pendukung suksesnya tranformasi organisasi untuk menghadapi Industri 4.0 karena termasuk ke dalam salah satu bagian dari digitalisasi. Budaya digital merupakan kunci untuk transformasi digital. Budaya Digital yang kuat akan meningkatkan produktivitas dan inovasi untuk mempertahankan keunggulan kompetitif perusahaan. Budaya digital juga sangat penting untuk memberdayakan dan menarik semua karyawan dalam memenangkan bakat (Microsoft, 2018).

Yayasan Pendidikan Telkom mendorong transformasi digital termasuk budaya digital yaitu adanya transformasi organisasi berupa perubahan struktur organisasi dengan adanya unit baru yakni digital transformation, synergy, and performance yang berfungsi untuk mengawal program digitalisasi di seluruh YPT Group. Secara garis besar unit Digital Transformation (DT) bertanggung jawab atas infrastruktur dan layanan teknologi informasi di Lakhar, serta pengembangan sistem informasi di YPT Group mulai dari lembaga pendidikan hingga unit bisnis. Peranan Information Technology (IT) menjadi sangat vital di dalam YPT Group dalam mendukung terwujudnya Smart Campus dan Smart Schools, serta membangun sistem kolaborasi antar unit dan lembaga di YPT Group. Khusus untuk Lakhar, hampir di semua unit telah memiliki sistem informasi seperti SIMKUG untuk keuangan, HRMIS untuk human capital, SIMLOG untuk logistik, KM online untuk performance, MONEV online untuk monitoring dan evaluasi, DASHBOARD YPT untuk pengambilan keputusan, dan lain sebagainya. Semua aktivitas di Yayasan Pendidikan Telkom sudah menggunakan perangkat atau sistem informasi dan digitalisasi, misalnya dalam surat menyurat adanya memo online atau nota dinas online, e-mail, group Whatsapp YPT Group, dan lain sebagainya. Hal tersebut sudah menjadi bukti bahwa semua aktivitas yang dilakukan di YPT 
Group sudah melibatkan sistem informasi dan memang diarahkan ke sana, dikarenakan coverage atau cakupan YPT itu luas mencakup seluruh Indonesia. Salah satu transformasi digital untuk mendorong penguatan budaya digital di YPT melalui upgrade absensi elektronik berupa long RFID dengan display hasil absensi langsung terlihat dalam layar. Di dalam tampilan layar terdapat urutan karyawan yang masuk paling awal dan akhir, termasuk karyawan yang terlambat atau tidak masuk kantor, hasil rekapitulasi bulanannya dilaporkan kepada para atasan. Setiap tahun ada apresiasi untuk karyawan terproduktif (lama jam kerja) atau disiplin. Hal ini mendorong pola perilaku disiplin absensi dan kehadiran para karyawan, yang sampai membuat karyawan bahkan berlari dari tempat parkir mereka agar bisa absen tepat waktu. Pola komunikasi dan koordinasi kerja antar karyawan di Yayasan Pendidikan Telkom sudah mengarah ke online (aplikasi digital), di antarannya dengan melalui group WhatsApp.

Untuk mengetahui fenomena budaya digital yang ada di Yayasan Pendidikan
Tabel 1. Preliminary study budaya digital

\begin{tabular}{|c|c|c|c|c|c|}
\hline No & $\begin{array}{c}\text { Dimensi } \\
\text { Budaya } \\
\text { Digital }\end{array}$ & STS & TS & $\mathrm{S}$ & SS \\
\hline 1. & Innovation & $0,00 \%$ & $20,83 \%$ & $50,00 \%$ & $29,17 \%$ \\
\hline 2. & $\begin{array}{l}\text { Data Driven } \\
\text { Decision } \\
\text { Making }\end{array}$ & $0,00 \%$ & $12,50 \%$ & $58,33 \%$ & $29,17 \%$ \\
\hline 3. & Collaboration & $0,00 \%$ & $4,17 \%$ & $37,50 \%$ & $58,33 \%$ \\
\hline 4. & Open Culture & $0,00 \%$ & $16,67 \%$ & $58,33 \%$ & $25,00 \%$ \\
\hline 5. & $\begin{array}{l}\text { Digital First } \\
\text { Mindset }\end{array}$ & $0,00 \%$ & $0,00 \%$ & $50,00 \%$ & $50,00 \%$ \\
\hline 6. & $\begin{array}{l}\text { Agility and } \\
\text { Flexibility }\end{array}$ & $0,00 \%$ & $0,00 \%$ & $41,67 \%$ & $58,33 \%$ \\
\hline 7. & $\begin{array}{l}\text { Customer } \\
\text { Centricity }\end{array}$ & $0,00 \%$ & $12,50 \%$ & $14,67 \%$ & $45,83 \%$ \\
\hline \multicolumn{2}{|c|}{ Budaya Digital } & $0,00 \%$ & $9,52 \%$ & $48,21 \%$ & $42,26 \%$ \\
\hline
\end{tabular}

Sumber: Data yang telah diolah (2018)

Keterangan:

STS : Sangat Tidak Setuju

TS : Tidak Setuju

S : Setuju

SS : Sangat Setuju

Telkom, peneliti menyebarkan kuesioner preliminary study kepada dua belas karyawan secara acak dan diperoleh hasil sebagaimana tertera dalam tabel 1 .

Hasil preliminary study menjelaskan bahwa, secara umum budaya digital yang diterapkan di kantor Yayasan Pendidikan Telkom sudah terimplementasi dengan baik, walaupun masih belum optimal karena masih ada 9,52\% yang merasakan implementasi budaya digital masih rendah. Jika ditelaah lebih jauh, beberapa 
dimensi budaya digital masih dirasakan rendah oleh responden dan perlu ditingkatkan di antarannya innovation $(20,83 \%)$, open culture $(16,67 \%)$, data driven decision making $(12,50 \%)$, dan customer centricity $(12,50 \%)$.

Transformasi digital berdampak tidak hanya terhadap Information Technology (IT) saja, akan tetapi juga untuk orang atau karyawan di dalam perusahaannya. Di sinilah budaya perusahaan masuk. Ketika berbicara tentang budaya, berarti sedang berbicara tentang bagaimana karyawan bekerja, apakah bersama-sama dan atau sebagai individu. Ketika sebuah perusahaan memiliki budaya digital yang kuat, akan berdampak pada indikator kunci kinerja yaitu substansial. Berbicara tentang budaya perusahaan berarti tentang bagaimana karyawan bekerja, yang artinya lebih mudah melihatnya dari kinerja karyawannya, yaitu bagaimana kinerja karyawan dipengaruhi dengan adanya budaya digital saat ini (Microsoft, 2018).

Faktor-faktor yang mempengaruhi kinerja karyawan baik hasil maupun perilaku kerja adalah kemampuan dan keahlian, pengetahuan seseorang tentang pekerjaannya, rancangan kerja, kepribadian atau karakter seseorang, motivasi kerja, kepemimpinan atau perilaku seorang pemimpin, gaya kepemimpinanan atau sikap seorang pemimpin, budaya organisasi, kepuasan kerja, lingkungan kerja, loyalitas, komitmen, dan disiplin kerja (Kasmir, 2016). Berdasarkan beberapa faktor yang sudah dijelaskan, salah satu faktor yang mempengaruhi kinerja karyawan adalah budaya organisasi. Budaya digital sendiri merupakan representasi dari DNA baru budaya organisasi. Budaya organisasi (perusahaan) memiliki kerangka kerja umum yang terdiri atas tiga elemen yakni: Visi dan Strategi, Kepemimpinan dan Orang-Orang, serta Proses dan Struktur Organisasi, di mana jika tiga elemen ini tidak memasukkan dimensi budaya digital maka perusahaan akan berjuang untuk beradaptasi dengan dunia digital (Levin, 2018). Budaya digital ini merupakan pengembangan dari budaya organisasi yang memfasilitasi adaptasi terhadap kondisi perubahan pasar, perubahan kebijakan pemerintah, teknologi baru, dan faktor lainnya (Welch dan Feeney, 2014; dalam Elijah, 2016). Karena penelitian yang secara khusus meneliti 
Tabel 2. Data NKI YPT

\begin{tabular}{|c|c|c|c|}
\hline \multirow{2}{*}{ NKI } & \multicolumn{3}{|c|}{ Tahun } \\
\cline { 2 - 4 } & 2015 & 2016 & 2017 \\
\hline $\begin{array}{c}\text { P1 } \\
\text { (Istimewa) }\end{array}$ & $9,6 \%$ & $1,6 \%$ & $1 \%$ \\
\hline $\begin{array}{c}\text { P2 (Baik } \\
\text { Sekali) }\end{array}$ & $74,2 \%$ & $88,7 \%$ & $56 \%$ \\
\hline P3 (Baik) & $16,2 \%$ & $9,7 \%$ & $43 \%$ \\
\hline $\begin{array}{c}\text { Total } \\
\text { Persentase }\end{array}$ & $100 \%$ & $100 \%$ & $100 \%$ \\
\hline
\end{tabular}

Sumber: Yayasan Pendikan Telkom (2017)

pengaruh budaya digital terhadap kinerja ini belum ada, maka peneliti mengambil pendekatan budaya organisasi sebagai salah acuan untuk penelitian terdahulu terkait pengaruhnya terhadap kinerja.

Penilaian kinerja di Kantor Badan Pelaksana Kegiatan Yayasan Pendidikan Telkom berdasar data NKI (Nilai Kinerja Individu) selama tiga tahun terakhir, seperti terlihat pada tabel 2 .

Berdasarkan hasil NKI pada tahun 2015, kategori P1 (Istimewa) memiliki persentase 9,6\%, P2 (Baik Sekali) memiliki persentase 74,2\% dan P3 (Baik) sebesar 16,2\%. Pada tahun 2016 kategori P1 (Istimewa) turun menjadi memiliki 1,6\%, sedangkan P2 (Baik Sekali) naik menjadi 88,7\%, dan P3 (Baik) turun menjadi 9,7\%. Pada tahun 2017 katagori P1 (Istimewa) turun menjadi 1\%, sedangkan P2 (Baik Sekali) turun menjadi 56\% dan P3 (Baik) naik menjadi 43\%. Data kinerja tersebut tidak ada yang menunjukkan nilai kinerja P4 (Kurang) dan P5 (Kurang Sekali). Data-data kinerja di atas menunjukkan bahwa hasil kinerja karyawan di Kantor Badan Pelaksana Kegiatan Yayasan Pendidikan Telkom yang fluktuatif dan pada tahun 2017 cenderung menurun, karena P1 menjadi semakin kecil dan P3 semakin besar. Sehingga kinerja karyawannya menunjukkan penurunan dan kurang memuaskan, masih belum sesuai dengan harapan perusahaan.

Berdasarkan fenomena yang telah peneliti jelaskan, maka peneliti tertarik untuk melakukan penelitian dengan mengangkat judul "Pengaruh

Budaya Digital terhadap Kinerja Karyawan di Yayasan Pendidikan Telkom (Studi Kasus Kantor Badan Pelaksana Kegiatan YPT)”.

Penelitian ini bertujuan untuk mengetahui:

(1) Budaya digital yang diterapkan Yayasan Pendidikan Telkom; (2) Kinerja karyawan Yayasan Pendidikan Telkom; (3) Seberapa besar pengaruh budaya digital terhadap kinerja karyawan Yayasan Pendidikan Telkom. 
$\begin{array}{ll}\text { TINJAUAN TEORI DAN } & \end{array}$

PENGEMBANGAN HIPOTESIS

Budaya Organisasi

Budaya organisasi merupakan

filosofi dasar organisasi yang memuat keyakinan, norma-norma, dan nilai-nilai bersama yang menjadi karakteristik inti tentang bagaimana cara melakukan sesuatu di dalam organisasi (Wibowo, 2016). Budaya organisasi adalah suatu hal yang karyawan rasakan dan bagaimana persepsinya menciptakan suatu pola teladan berupa kepercayaan, nilai-nilai, dan harapan (Zainal dkk, 2017). Budaya organisasi merupakan suatu sistem nilai yang diyakini, diterapkan, dan dikembangkan secara terus-menerus yang berfungsi sebagai perekat, pemersatu, identitas, citra, dan pembeda dari organisasi lainnya, yang dapat dipelajari, diwariskan kepada generasi berikutnya, dan dapat dijadikan acuan perilaku manusia di dalam organisasi untuk mencapai tujuan organisasi yang telah ditetapkan (Umam, 2018).

Berdasarkan penjelasan pengertian budaya organisasi menurut para ahli yang sudah dijelaskan, dapat diambil kesimpulan bahwa budaya organisasi adalah suatu hal yang berkaitan dengan kepercayaan, nilai, normanorma perilaku, harapan, dan menjadi karakteristik inti tentang bagaimana cara melakukan sesuatu di dalam organisasi, serta menjadi dasar identitas suatu organisasi dan menjadi pembeda dengan organisasi lainnya.

\section{Perubahan Budaya Organisasi}

Budaya organisasi tidak hadir begitu saja, akan tetapi harus diciptakan, dipelihara, dan diperkuat, bahkan dapat diubah agar sesuai dengan tuntutan internal maupun eksternal organisasi (Soetopo, 2012). Perubahan budaya organisasi diperlukan agar dapat bertahan terhadap goncangan yang timbul sebagai akibat dari perubahan lingkungan. Karena banyak organisasi mengalami kemunduran yang diakibatkan oleh ketidakmampuannya menyesuaikan diri dengan perubahan lingkungan (Wibowo, 2016). Meskipun budaya organisasi penting, manajer dan karyawan dianjurkan untuk selalu memastikan kesesuaian budaya dengan lingkungan. Organisasi perlu meninjau kembali budaya dan penerapannya, karena tidak menutup kemungkinan ada hal yang perlu direvisi. Hal tersebut perlu dilakukan perusahaan agar 
memiliki budaya yang adaptif untuk dapat bertahan (Amir, 2017). Agar karyawan tetap bertahan di dalam perusahaan, maka budaya perusahaan harus bersifat dinamis, yang artinya budaya perusahaan harus terbuka, adaptif, dan siap berubah sesuai dengan yang terjadi di lingkungan internal maupun eksternal perusahaan (Umam, 2018). Budaya organisasi sendiri dapat berkembang menjadi menjadi budaya digital karena beradaptasi terhadap kondisi perubahan pasar, perubahan kebijakan pemerintah, teknologi baru, dan faktor lainnya (Welch dan Feeney, 2014; dalam Elijah, 2016).

Berdasarkan penjelasan dari para ahli, dapat diambil kesimpulan bahwa budaya organisasi suatu perusahaan dapat berubah sesuai dengan perkembangan lingkungannya. Organisasi dituntut untuk mampu beradaptasi dengan perubahan yang terjadi agar mampu untuk bertahan. Seperti sekarang ini dengan adanya perkembangan digital teknologi, menghadirkan budaya baru ke perusahaan yaitu budaya digital. Budaya digital hadir dipengaruhi oleh perubahan lingkungan organisasi yaitu digitalisasi.

\section{Budaya Digital}

Peningkatan teknologi komunikasi dan koneksi virtual telah membuka dunia untuk caracara baru dalam memperoleh, mengembangkan, dan mengelola bakat dan pekerjaan, termasuk mengubah cara pekerjaan didistribusikan. Selain itu, juga mengubah persepsi mengenai pekerjaan, orang-orang di dalamnya dan budaya kerja secara keseluruhan. Teknologi digital telah secara dramatis berdampak pada budaya di sekitar tempat kerja dan dalam bekerja, pemanfaatan teknologi digital memudahkan efektivitas kerja dan memperluas sasaran kerja yang ingin dicapai (Buchanan et al., 2016).

Budaya digital sendiri diibaratkan sebagai satu set dari tujuh atribut kunci yaitu Innovation, Data-driven Decision-Making, Collaboration, Open Culture, Digital First Mindset, Agility and Flexibility, dan Customer Centricity (Buvat et al., 2017). Budaya digital merupakan asumsi dasar yang mendasari, berakar kuat, nilai, keyakinan, dan norma yang menjadi ciri bagaimana suatu organisasi mendorong dan mendukung penggunaan teknologi untuk menyelesaikan pekerjaan dengan cara yang paling efektif 
(Microsoft, 2018). Budaya digital ini mengacu pada pengaruh budaya lingkungan media baru dan proses digitalisasi, di mana menurut beberapa pendekatan, budaya digital telah muncul dengan fenomena media baru (Yegen, 2019). Sementara menurut Turkoglu dan Turkoglu (2019) secara singkat budaya digital adalah bentuk budaya baru yang terbentuk dengan digitalisasi.

Berdasarkan penjelasan para ahli ataupun literatur di atas, dapat diambil kesimpulan bahwa budaya digital merupakan nilai, keyakinan, dan norma yang dianut suatu organisasi, dan terdiri dari berbagai atribut atau kepercayaan yang mendorong serta mendukung penggunaan teknologi untuk menyelesaikan pekerjaan secara efektif.

\section{Dimensi Budaya Digital}

Pada penelitian ini, peneliti meunggunakan tujuh atribut atau dimensi dalam budaya digital yaitu (Buvat et al., 2017):

\section{Innovation (Inovasi). Prevalensi} atau kebiasaan perilaku organisasi yang mendukung karyawan untuk melakukan

pengambilan risiko dan eksplorasi ide-ide baru.

2. Data-Driven

(Pengambilan Keputusan Berdasarkan Data). Merupakan indikator di mana organisasi menggunakan data dan analisis untuk membuat keputusan bisnis yang lebih baik atau bisa dikatakan bahwa organisasi melakukan pengambilan keputusan berdasarkan data yang dimiliki.

3. Collaboration (Kolaborasi). Organisasi menciptakan tim lintas fungsional dan antar departemen untuk mengoptimalkan keahlian perusahaan yang berorientasi pada pencapaian tujuan organisasi.

\section{Open Culture (Budaya Terbuka):} merupakan indikator di mana organisasi terbuka dengan kemitraan jaringan eksternal seperti vendor pihak ketiga, startup (perusahaan baru) atau pelanggan, yang intinya organisasi terbuka dengan dunia luar atau eksternal.

\section{Digital First Mindset (Digitalisasi).} Organisasi menggunakan pola pikir di mana solusi digital adalah cara utama untuk memecahkan solusi masalah ataupun meningkatkan kinerja organisasi ke depan. Organisasi sudah terbiasa berinteraksi dengan halhal yang berkaitan dengan digital seperti 
smartphone, aplikasi atau software, sistem

informasi, internet, ataupun website yang

membantu untuk mempermudah dalam melakukan pekerjaan.

6. Agility and Flexibility (Kelincahan dan Fleksibilitas). Merupakan indikator di mana organisasi mampu dengan cepat dan dinamis dalam pengambilan keputusan, serta kemampuan organisasi untuk beradaptasi dengan tuntutan teknologi yang berubah-ubah.

7. Customer Centricity (Sentralitas Pelanggan atau Pusat Perhatian Pelanggan). Organisasi menggunakan solusi digital untuk memperluas basis pelanggan dengan mengubah pengalaman pelanggan untuk menciptakan produk baru atau bisa dikatakan dengan penggunaan teknologi digital organisasi mampu membuat keterlibatan pelanggan menjadi lebih dekat dan kuat.

\section{Kinerja Karyawan}

Kinerja karyawan adalah hasil kerja dan perilaku kerja seseorang yang telah dicapai dalam menyelesaikan tugas-tugas dan tanggung jawab yang diberikan dalam periode waktu tertentu (Kasmir, 2016).
Kinerja pegawai ialah perwujudan dari kemampuan dalam bentuk karya nyata atau hasil kerja yang dicapai pegawai dari hasil mengemban tugas dan pekerjaan yang diberikan oleh perusahaan (Priansa, 2017). Kinerja karyawan merupakan hasil kerja yang dicapai oleh individu sesuai dengan peran atau tugasnya dalam periode waktu tertentu, yang dihubungkan dengan ukuran nilai atau standar tertentu dari organisasi tempat di mana individu tersebut bekerja (Umam, 2018).

Dari penjelasan yang sudah dijelaskan oleh para ahli, dapat diambil kesimpulan bahwa kinerja karyawan adalah hasil dari suatu pekerjaan atau tugas yang diberikan oleh organisasi kepada karyawannya dalam kurun waktu atau periode tertentu guna mencapai tujuan organisasi.

\section{Dimensi Kinerja Karyawan}

Pada penelitian ini, peneliti melakukan pengukuran penilaian kinerja karyawan dengan menggunakan standar pekerjaan, dapat diukur melalui dimensi (Bangun, 2012):

1. Jumlah Pekerjaan. Dimensi ini memperlihatkan jumlah pekerjaan yang dihasilkan individu atau kelompok sebagai persyaratan menjadi standar pekerjaan di mana karyawan dituntut harus memenuhi 
persyaratannya baik itu pengetahuan, keterampilan, maupun kemampuan yang sesuai. Sehingga dari persyaratan itulah dapat diketahui berapa jumlah karyawan yang dibutuhkan untuk dapat mengerjakan pekerjaan tersebut atau setiap karyawan dapat mengerjakan berapa unit pekerjaan.

2. Kualitas Pekerjaan. Dimensi ini mengharuskan setiap karyawan yang ada di dalam perusahaan memenuhi persyaratan tertentu untuk dapat menghasilkan pekerjaan yang sesuai dengan kualitas yang dituntut dari pekerjaan tersebut. Artinya, kinerja karyawan bisa dikatakan baik apabila dapat menghasilkan pekerjaan sesuai dengan persyaratan kualitas yang dituntut dari pekerjaannya tersebut.

3. Ketepatan Waktu. Pada dimensi ini, karyawan diharuskan untuk bisa menyelesaikan pekerjaan tepat pada waktunya.

4. Kehadiran. Dimensi ini mencakup tingkat kehadiran karyawan dalam mengerjakan pekerjaannya.

5. Kemampuan Kerja Sama. Dimensi ini menilai kemampuan karyawan dalam

\begin{tabular}{|c|c|}
\hline $\begin{array}{l}\text { BUDAYA DIGITAL } \\
\qquad(X)\end{array}$ & $\begin{array}{l}\text { KINERJA KARYAWAN } \\
\qquad(Y) \\
\text { 1. Jumlah Pekerjaan } \\
\text { 2. Kualitas Pekerjaan } \\
\text { 3. Ketepatan Waktu } \\
\text { 4. Kehadiran } \\
\text { 5. Kemampuan } \\
\quad \text { Kerjasama }\end{array}$ \\
\hline
\end{tabular}

\section{Gambar 1. Kerangka Pemikiran}

Sumber: Data yang telah diolah (2018)

bekerjasama dengan rekan kerjanya yang lain.

Berdasarkan penjelasan yang sudah dijelaskan, kerangka pemikiran dan hipotesis di dalam penelitian ini tertera pada gambar 1 .

H0 : Tidak terdapat pengaruh budaya digital terhadap kinerja karyawan Yayasan

Pendidikan Telkom.

H1 : Terdapat pengaruh budaya digital terhadap kinerja karyawan Yayasan

Pendidikan Telkom.

\section{METODE RISET}

Pada penelitian ini, peneliti menggunakan metode penelitian kuantitatif. Berdasarkan tujuan penelitian menggunakan tujuan deskriptif. Peneliti menggunakan tipe penyelidikan jenis kausal. Berdasarkan keterlibatan penelitian, peneliti tidak melakukan intervensi data. Sehingga data yang diolah merupakan data dari responden tanpa ada perubahan di dalam isinya. Berdasarkan unit analisis, peneliti menggunakan jenis unit analisis 
individu. Berdasarkan setting penelitian, peneliti menggunakan non contrived setting dan untuk waktu pelaksanaan penelitian, peneliti menggunakan metode cross section.

Pada penelitian ini, peneliti memakai skala ordinal untuk mengukur masingmasing indikator variabel yang diteliti. Sedangkan dalam metode penskalaan, peneliti menggunakan skala likert.

Populasi dalam penelitian ini adalah karyawan Yayasan Pendidikan Telkom yang berjumlah 74 karyawan. Pada penelitian ini, peneliti menggunakan teknik sampling berupa nonprobability sampling yaitu sampling jenuh atau sensus. Alasan memilih sampling jenuh atau sensus dikarenakan populasinya berjumlah sedikit, sehingga diambil keseluruhan populasi untuk dijadikan sampel yaitu sebanyak 74 karyawan.

Di dalam penelitian ini, peneliti mengumpulkan data primer melalui kuesioner dan hasil wawancara dengan narasumber dari Yayasan Pendidikan Telkom, sedangkan data sekunder berupa buku-buku sebagai teori, artikel, jurnal, data internal perusahaan, dan pihak atau sumber lainnya yang dianggap relevan.

Pada penelitian ini, terdapat dua jenis variabel yaitu variabel bebas (X) dan variabel terikat (Y). Variabel bebas (X) dalam penelitian ini adalah Budaya Digital, sedangkan dimensi pengukuran yang digunakan adalah Innovation, Data-Driven Decision-Making, Collaboration, Open Culture, Digital First Mindset, Agility and Flexibility, dan Customer Centricity (Buvat et al., 2017). Variabel terikat (Y) pada penelitian ini adalah Kinerja Karyawan, sedangkan dimensi pengukuran yang digunakan adalah Jumlah Pekerjaan, Kualitas Pekerjaan, Ketepatan Waktu, Kehadiran, dan Kemampuan Kerjasama (Bangun, 2012).

Berdasarkan variabel-variabel yang sudah dijelaskan, maka variabel operasional yang akan digunakan sebagai alat pengumpulan data dalam penelitian tertera pada tabel 3 .

Untuk mempermudah dalam mengolah data, peneliti menggunakan software IBM SPSS versi 25. Uji validitas peneliti mengambil sebanyak 30 responden dengan taraf signifikansi 5\% sehingga didapatkan $\mathrm{r}$ tabel sebesar 0,361 . Hasil uji validitas variabel $\mathrm{X}$ (budaya digital) dan variabel Y (kinerja karyawan) dapat disimpulkan 
Tabel 3. Operasional Variabel

\begin{tabular}{|c|c|c|}
\hline Variabel & Dimensi & Indikator \\
\hline \multirow{8}{*}{$\begin{array}{c}\text { Budaya } \\
\text { Digital } \\
\text { (X) } \\
\text { (Buvat et } \\
\text { al., 2017) }\end{array}$} & Innovation & $\begin{array}{l}\text { Eksplorasi ide-ide } \\
\text { baru } \\
\text { pengambilan } \\
\text { risiko. }\end{array}$ \\
\hline & $\begin{array}{c}\text { Data-Driven } \\
\text { Decision- } \\
\text { Making }\end{array}$ & $\begin{array}{l}\text { Penggunaan data } \\
\text { dan analisa untuk } \\
\text { pengambilan } \\
\text { keputusan. }\end{array}$ \\
\hline & Collaboration & $\begin{array}{l}\text { Kolaborasi lintas } \\
\text { fungsional. }\end{array}$ \\
\hline & Open Culture & $\begin{array}{l}\text { Organisasi terbuka } \\
\text { dengan eksternal. }\end{array}$ \\
\hline & $\begin{array}{c}\text { Digital First } \\
\text { Mindset }\end{array}$ & $\begin{array}{l}\text { Pola pikir dan } \\
\text { solusi digital. }\end{array}$ \\
\hline & \multirow{2}{*}{$\begin{array}{l}\text { Agility and } \\
\text { Flexibility }\end{array}$} & $\begin{array}{l}\text { Cepat dan dinamis } \\
\text { dalam } \\
\text { pengambilan } \\
\text { keputusan. }\end{array}$ \\
\hline & & \begin{tabular}{l}
\multicolumn{2}{l}{ Beradaptasi } \\
dengan tuntutan \\
teknologi yang \\
berubah.
\end{tabular} \\
\hline & $\begin{array}{l}\text { Customer } \\
\text { Centricity }\end{array}$ & $\begin{array}{lr}\text { Perluasan } & \text { basis } \\
\text { pelanggan } & \text { dan } \\
\text { keterlibatan } & \\
\text { pelanggan. } & \end{array}$ \\
\hline \multirow{5}{*}{$\begin{array}{c}\text { Kinerja } \\
\text { Karyawan } \\
\text { (Y) } \\
\text { (Bangun, } \\
\text { 2012) }\end{array}$} & $\begin{array}{c}\text { Jumlah } \\
\text { Pekerjaan }\end{array}$ & $\begin{array}{lr}\text { Pencapaian } & \text { target } \\
\text { dan } & \text { jumlah } \\
\text { pekerjaan } & \text { yang } \\
\text { dihasilkan. } & \end{array}$ \\
\hline & $\begin{array}{l}\text { Kualitas } \\
\text { Pekerjaan }\end{array}$ & $\begin{array}{l}\text { Kesesuaian dengan } \\
\text { standar atau } \\
\text { persyaratan. }\end{array}$ \\
\hline & $\begin{array}{c}\text { Ketepatan } \\
\text { Waktu }\end{array}$ & $\begin{array}{l}\text { Ketepatan waktu } \\
\text { dalam } \\
\text { penyelesaian } \\
\text { pekerjaan. }\end{array}$ \\
\hline & Kehadiran & $\begin{array}{l}\text { Tingkat kehadiran } \\
\text { dan waktu kerja } \\
\text { yang efektif. }\end{array}$ \\
\hline & $\begin{array}{c}\text { Kemampuan } \\
\text { Kerja Sama }\end{array}$ & $\begin{array}{l}\text { Kerja sama antar } \\
\text { karyawan. }\end{array}$ \\
\hline
\end{tabular}

Sumber: Data yang telah diolah (2018)

bahwa keseluruhan item pernyataan budaya

digital dan kinerja karyawan dinyatakan

valid. Hal ini dikarenakan keseluruhan item

pernyataan memiliki $\mathrm{r}$ hitung $>\mathrm{r}$ tabel,

yaitu r hitung lebih besar dari 0,361.
Kemudian untuk hasil uji reliabilitas dapat diketahui bahwa variabel budaya digital memiliki nilai Alpha Cronbach sebesar 0,934 dan dinyatakan reliabel. Kemudian dapat disimpulkan juga bahwa nilai Alpha Cronbach variabel kinerja karyawan adalah sebesar 0,917 dan dinyatakan reliabel. Setelah uji validitas dan reliabilitas, maka dilakukan analisis statistik deskriptif, transformasi data ordinal menjadi interval menggunakan Method of Successive Interval atau MSI menggunakan program MSI pada Microsoft Excel dengan bantuan software pendukung yaitu Stat97.Xla, uji asumsi klasik (uji normalitas dan uji heteroskedastisitas), analisis regresi sederhana, uji koefisien determinasi, dan pengujian hipotesis.

\section{HASIL PENELITIAN DAN PEMBAHASAN}

\section{Analisis Statistik Deskriptif}

Pengukuran analisis deskriptif di dalam penelitian ini menggunakan kuesioner, di mana setiap item pernyataan disertai dengan empat alternatif jawaban yaitu, sangat setuju, setuju, tidak setuju, dan sangat tidak setuju.

Hasil penghitungan yang digunakan dalam pembuatan garis kontinum sesuai dengan cara yang dijelaskan oleh Riduwan dan Kuncoro (2017), sebagaimana berikut: 
1. Peneliti melakukan rekapitulasi data dengan cara setiap jawaban yang diberikan responden dihubungkan dengan bentuk pernyataan atau dukungan sikap yang diungkapkan dengan katakata yaitu untuk skala tertinggi tanggapan yang diberikan pada penelitian ini adalah 4 untuk kategori "Sangat Setuju" dan skala terendah adalah 1 untuk kategori "Sangat Tidak Setuju".

2. Menghitung skor ideal atau tertinggi dan skor terendah. Skor tertinggi $=$ jumlah responden $\times 4=$ $74 \times 4=296$. Skor terendah $=$ jumlah responden $\times 1=74 \times 1=$ 74.

3. Menghitung nilai persentase skor ideal atau tertinggi dan skor terendah. Skor tertinggi $=(($ skor tertinggi) $/($ skor tertinggi) $) \times 100 \%$ $=(296 / 296) \times 100 \%=100 \%$. Skor terendah $=(($ skor terendah $) /$ $($ skor tertinggi $)) \times 100 \%=(74 /$ 296) $\times 100 \%=25 \%$.
Tabel 4. Klasifikasi interpretasi skor

\begin{tabular}{|c|c|}
\hline Keterangan Kelas & Rentang Persentase \\
\hline Sangat Rendah & $25 \%-43,75 \%$ \\
\hline Rendah & $>43,75 \%-62,50 \%$ \\
\hline Tinggi & $>62,50 \%-81,25 \%$ \\
\hline Sangat Tinggi & $>81,25 \%-100 \%$ \\
\hline
\end{tabular}
Sumber: Data yang telah diolah (2018)

4. Menghitung nilai rentang persentase. Persentase selisih $=$ skor tertinggi - skor terendah $=100 \%-25 \%=75 \%$. Persentase rentang $=$ persentase selisih $\div$ jumlah kategori pilihan $=75 \% \div 4=$ $18,75 \%$.

5. Dari hasil perhitungan nilai persentase dan nilai rentang persentase, dapat diperoleh hasil klasifikasi sebagaimana tertera pada tabel 4. Hasil perhitungan kuesioner untuk variabel budaya digital masuk ke dalam kategori sangat tinggi yaitu $85 \%$. Jadi, dapat disimpulkan bahwa budaya digital yang diterapkan di Yayasan Pendidikan Telkom sudah cukup tinggi. Untuk variabel kinerja karyawan juga masuk ke dalam kategori sangat tinggi yaitu $82 \%$. Jadi, dapat disimpulkan bahwa kinerja karyawan yang ada di Yayasan Pendidikan Telkom sudah cukup tinggi. 


\section{Uji Asumsi Klasik}

Uji Normalitas

Nilai signifikansi yang diperoleh dari nilai Asymp. Sig. (2-tailed) di dalam penelitian ini yaitu 0,052 , sedangkan tingkat signifikansi yang digunakan di dalam penelitian ini yaitu $5 \%$ atau 0,05 . Sehingga diperoleh kesimpulan bahwa nilai Asymp. Sig. $(0,052)>$ nilai signifikansi $(0,05)$ yang artinya bahwa data terdistribusi normal.

Uji Heteroskedastisitas

Uji heteroskedastisitas memperoleh hasil nilai signifikansi sebesar 0,179 . Hal ini menunjukkan bahwa nilai signifikansi dari variabel bebas lebih besar dari 0,05 yang artinya tidak terjadi heteroskedastisitas.

\section{Analisis Regresi Linier Sederhana}

Menurut Riduwan dan Kuncoro (2017) menjabarkan rumus untuk regresi linier sederhana adalah sebagai berikut:

$$
\hat{\mathrm{Y}}=\mathrm{a}+\mathrm{bX}
$$

Keterangan:

$\hat{\mathrm{Y}} \quad=$ (baca $\mathrm{Y}$ topi) subjek variabel terikat yang diproyeksikan.
$\mathrm{X}=$ variabel bebas yang mempunyai nilai tertentu untuk diprediksikan.

a = nilai konstanta harga $\mathrm{Y}$ jika $\mathrm{X}=0$.

$\mathrm{b} \quad=$ nilai arah sebagai penentu ramalan (prediksi) yang menunjukkan nilai peningkatan (+) atau nilai penurunan (-) variabel Y.

Di dalam penelitian ini persamaan regresi linier sederhana dapat ditulis seperti berikut:

$$
\hat{\mathrm{Y}}=7,097+0,491 \mathrm{X}
$$

Persamaan tersebut dapat dijelaskan melalui beberapa poin kesimpulan yaitu: (1) Konstanta bernilai sebesar 7,097 yang artinya apabila budaya digital sebagai variabel independen (X) bernilai nol maka variabel dependen (Y) yaitu kinerja karyawan akan memiliki nilai sebesar 7,097; (2) Arti nilai ramalan atau prediksi (b) sebesar 0,491 yaitu apabila budaya digital sebagai variabel independen $(\mathrm{X})$ meningkat sebesar satu satuan, maka variabel dependen (Y) yaitu kinerja karyawan akan meningkat sebesar 0,491. Koefisien regresi tersebut bernilai positif (+), sehingga dapat diartikan bahwa arah pengaruh variabel independen (budaya digital) terhadap variabel dependen (kinerja karyawan) adalah positif yang berarti peningkatan. 


\section{Uji Koefisien Determinasi}

Peneliti memperoleh hasil bahwa koefisien korelasi (R) sebesar 0,629 dan nilai koefisien determinasi ( $\mathrm{R}$ Square) diperoleh sebesar 0,395 mengandung arti bahwa pengaruh variabel budaya digital terhadap variabel kinerja karyawan di dalam penelitian ini adalah sebesar 39,5\%, sedangkan sisanya sebesar $60,5 \%$ kinerja karyawan Yayasan Pendidikan Telkom dipengaruhi oleh variabel lainnya yang tidak diteliti di dalam penelitian ini.

\section{Pengujian Hipotesis}

Hasil perhitungan memperoleh hasil bahwa t hitung sebesar 6,857. Pada penelitian ini, peneliti menggunakan taraf signifikansi $(\alpha)$ sebesar $5 \%$ dan derajat kebebasan atau degree of freedom $(\mathrm{df})=$ banyak observasi (n) - banyaknya variabel bebas dan terikat $(\mathrm{k})=74-2=72$, menghasilkan $\mathrm{t}$ tabel sebesar 1,99346. Sehingga pada penelitian ini dapat diambil kesimpulan bahwa t hitung $(6,857)>t$ tabel $(1,99346)$, yang artinya hipotesis alternatif (H1) diterima yaitu terdapat pengaruh budaya digital terhadap kinerja karyawan Yayasan Pendidikan Telkom.

\section{KESIMPULAN DAN SARAN}

\section{Kesimpulan}

1. Budaya digital yang diterapkan Yayasan Pendidikan Telkom tergolong sangat tinggi yaitu $85 \%$. Hal ini dikarenakan Yayasan Pendidikan Telkom mempunyai pola pikir digital dalam pelaksanaan proses pekerjaan yang dilakukan perusahaan maupun karyawannya. Terbukti dengan hampir semua aktivitas di Yayasan Pendidikan Telkom sudah menggunakan perangkat atau sistem informasi dan digitalisasi.

2. Kinerja karyawan Yayasan Pendidikan Telkom menurut hasil penelitian tergolong sangat tinggi yaitu $82 \%$. Hal ini dikarenakan hampir secara keseluruhan rata-rata kinerja karyawannya tergolong sangat tinggi, sesuai informasi yang diperoleh dari Ketua YPT bahwa pegawai kantor Yayasan haruslah dari orang-orang yang terpilih saja.

3. Budaya digital berpengaruh positif terhadap kinerja karyawan Yayasan Pendidikan Telkom. Hubungan antara budaya digital dengan kinerja karyawan sebesar 0,395 mengandung arti bahwa 
pengaruh budaya digital terhadap

kinerja karyawan di dalam

penelitian ini adalah sebesar

$39,5 \%$, sedangkan sisanya sebesar

$60,5 \%$ kinerja karyawan di

Yayasan Pendidikan Telkom

dipengaruhi oleh variabel lainnya

yang tidak diteliti di dalam

penelitian ini. Kesimpulan dari

penelitian ini yaitu apabila budaya

digital mengalami peningkatan,

maka kinerja karyawan juga akan

ikut meningkat.

\section{Saran}

Aspek Teoritis

Saran peneliti untuk peneliti selanjutnya diharapkan dapat melakukan penelitian pada perusahaan yang berbeda agar lebih beragam hasil penelitiannya, sehingga dapat mengetahui bagaimana hubungan setiap variabel yang diteliti di berbagai perusahaan yang lebih luas. Selain itu, peneliti selanjutnya dapat melakukan penelitian dengan menggunakan variabel yang sama namun dengan metode analisis faktor atau menambahkan variabel dependen yang berbeda seperti rekrutmen, kepuasan kerja, kompensasi, motivasi kerja, dan lain sebagainya, dengan menggunakan metode analisis penelitian yang berbeda seperti analisis regresi linier berganda atau metode path analysis, agar penelitian selanjutnya lebih beragam.

Aspek Praktis

Saran praktis yang akan diberikan peneliti kepada Yayasan Pendidikan Telkom adalah sebagai berikut:

1. Secara keseluruhan penerapan budaya digital di Yayasan Pendidikan Telkom sudah sangat tinggi, sehingga seiring dengan perkembangan teknologi yang semakin maju maka perusahaan dapat terus menjaga dan meningkatkan penerapan budaya digitalnya. Yayasan Pendidikan Telkom dapat memberikan fasilitas berupa kegiatan brainstorming atau focus group discussion yang bermanfaat untuk mengasah ide-ide baru karyawan dan setiap karyawan yang mengusulkan ide-ide baru diberikan apresiasi khusus, selain itu adanya pemberian insentif untuk beberapa pegawai yang hasil inovasinya masuk dalam lomba inovasi misal di Telkom Group seperti Hack Idea. 
Journal of Management Vol. 16, No. 2, $2019: 129-148$

2. Secara keseluruhan kinerja

karyawan di Yayasan Pendidikan

Telkom sudah sangat tinggi,

sehingga perusahaan dapat terus

membangun dan menjaga kinerja

karyawan yang sudah tinggi pada

kondisi saat ini agar karyawan

dapat terus meningkatkan

kinerjanya. 


\section{DAFTAR PUSTAKA}

Amir, M. T. (2017). Perilaku Organisasi. (Cetakan Kesatu). Jakarta: Kencana.

Bangun, W. (2012). Manajemen Sumber Daya Manusia. Jakarta: Erlangga.

Brett, J. (2019). Evolving Digital Leadership: How to Be a Digital Leader in Tomorrow's Disruptive World. Forest Lodge, New South Wales, Australia: Apress.

Buchanan, J., Kelley, B., dan Hatch, A. (2016). Digital Workplace and Culture: How Digital Technologies are Changing the Workforce and How Enterprise Can Adapt and Evolve. London: Deloitte Development LLC.

Buvat, J., Crummenerl, C., Kar, K., Sengupta, A., Solis, B., Aboud, C., dan Aoufi, H. E. (2017). The Digital Culture Challenge: Closing the Employee-Leadership Gap. Paris: Capgemini.

Cahyono, E. (2018). Revolusi Industri 4.0 dan Transformasi Organisasi Pemerintah. Diakses dari http://setkab.go.id/revolusi-industri-4-0-dan-transformasi-organisasi-pemerintah/. [3 September 2018].

Elijah, N. (2016). Digital Culture versus Change. IOSR Journal of Engineering (IOSRJEN), Vol. 06, No. 08, 21-34.

Endarwati, O. (2017). Industri 4.0 Ciptakan Peluang Baru. Diakses dari http://koransindo.com/page/news/2017-05-03/2/3/Industri_4_0_Ciptakan _ Peluang_Baru. [3 September 2018].

Igen, R. (2018). Teknologi Terkini: Apa itu Industri 4.0 ? Dan apa saja elemen yang harus ada?. Diakses dari https://mobnasesemka.com/apa-itu-industri-4-0/. [3 September 2018].

Kasmir. (2016). Manajemen Sumber Daya Manusia (Teori dan Praktik). (Cetakan Kedua). Jakarta: PT RajaGrafindo Persada.

Kementrian Perindustrian Republik Indonesia. (2018). Siaran Pers: Making Indonesia 4.0: Strategi RI Masuki Revolusi Industri Ke-4. Diakses dari http://www.kemenperin.go.id/artikel/18967/MakingIndonesia-4.0:-Strategi-RI-Masuki-Revolusi-Industri-Ke-4. [3 September 2018].

Levin, M. (2018). 9 Ways Digitalization Is Disrupting Your Culture, and 3 Ways You Must Respond. Diakses dari https://www.inc.com/marissa-levin/10-was-digitalization-is-disrupting-your-culture- 
3-ways-you-must-respond.html. [19 Februari 2019].

Microsoft. (2018). Digital Culture: Your Competitive Advantage. Irlandia: Microsoft.

Novalius, F. (2018). Economy Sektor Riil: Apa Itu Industri 4.0? Ini Penjelasan Presiden Jokowi. Diakses dari https://economy.okezone.com/read/2018/04/04/320/1881871/apa-itu-industri-4-0ini-penjelasan-presiden-jokowi. [3 September 2018].

Priansa, D. J. (2017). Manajemen Kinerja Kepegawaian. (Cetakan Kesatu). Bandung: CV Pustaka Setia. Riduwan, dan Kuncoro, E. A. (2017). Cara Menggunakan dan Memaknai Path Analysis (Analisis Jalur). (Cetakan Ketujuh). Bandung: Alfabeta.

Soetopo, H. (2012). Perilaku Organisasi Teori dan Praktik dalam Bidang Pendidikan. (Cetakan Kedua). Bandung: PT Remaja Rodakarya.

Turkoglu, H. S., dan Turkoglu, S. (2019). The Digital Cultural Identity on The Space Drawed in Virtual Games and Representative. Dalam B. O. Dogan, dan D. G. Unlu, Handbook of Research on Examining Cultural Policies Through Digital Communication (hal. 143). Hershey: IGI Global.

Umam, K. (2018). Perilaku Organisasi. (Cetakan Ketiga). Bandung: CV Pustaka Setia.

Wibowo. (2016). Budaya Organisasi: Sebuah Kebutuhan untuk Meningkatkan Kinerja Jangka Panjang. (Cetakan Keempat). Jakarta: PT RajaGrafindo Persada.

Yayasan Pendidikan Telkom. (2017). Laporan Tahunan Yayasan Pendidikan Telkom 2017.

Yegen, C. (2019). Digitalization of Labor: Women Making Sales Through Instagram and Knitting Accounts. Dalam R. Y1lmaz, M. N. Erdem, dan F. Resuloglu, Handbook of Research on Transmedia Storytelling and Narrative Strategies (hal. 250). Hershey: IGI Global.

Zainal, V. R., Hadad, M. D., dan Ramly, M. (2017). Kepemimpinan dan Perilaku Organisasi. (Cetakan Kedua Belas). Jakarta: PT RajaGrafindo Persada. 